\title{
The State of Dancingness: Staying with Leaving
}

\section{Cover Page Footnote}

The author acknowledges the support of her supervision team: Dr Jonathan W Marshall, Dr Marcella Polain (Edith Cowan University), Prof Cat Hope (Monash University). The author also acknowledges the generous reviewer feedback received in response to this article. 


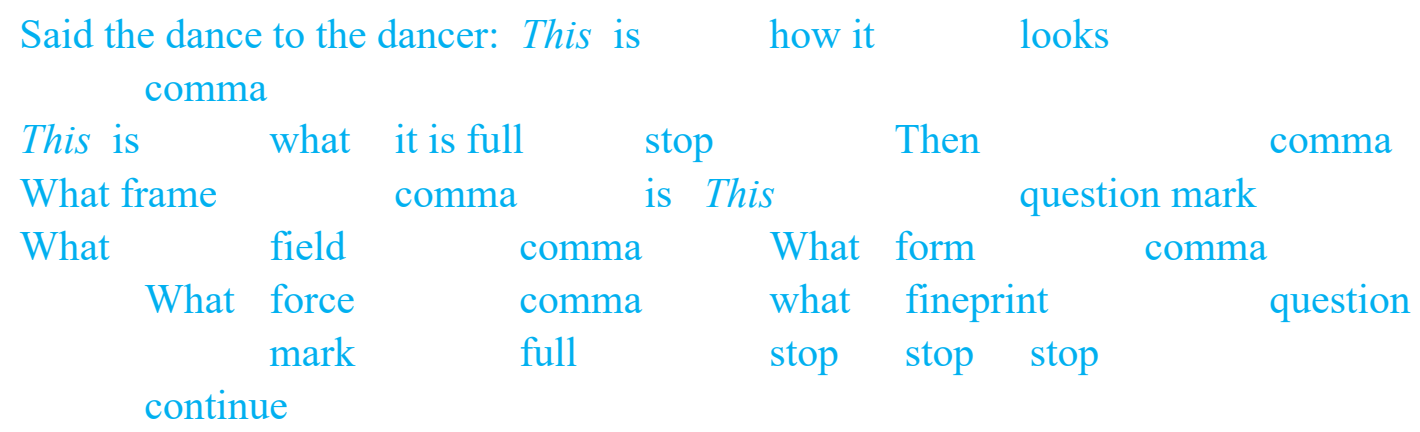

After Cixous' "State of Drawingness,"1 this paper proposes a State of Dancingness as a method of inhabiting my ongoing research practice of writing as dancing. Writing as dancing is an attempt to write like I dance, ${ }^{2}$ and, rather than experiential document or creative response, it is the practice of writing activated as a 'continuation' of dancing. The work proposes that the dancer begin on the page from the vantage and experience of entering the stage as a solo improvising performer. Emergent content is thus revealed as textual bodies of evidence, as danced documents you can hold in your hands, arrived from associational shifts, compositional rigor and practiced energetic states. There is a conscious application of writing as a dancer, of leaning into imagination, association, tone and pacing on the page, as on the stage, and an applied and driven presence. The aligning with Cixous' "State of Drawingness" is as shared axiom in excavating and speaking from inside the rendering of making a new work, in my case; what it is to be in the middle of writing as dancing.

As a dancer, working primarily with solo dance improvisation, I am acutely attentive to the decision making and sensorial information of my body in movement, and practiced at responding to emergent content in the moment of performance. This accessing and applying of dancerly attention to the act of writing generates a State of Dancingness. As a solo artist and researcher inside my own practice I resist the idea of "the assumption that subjective experience is easy to articulate and easier to access than objective knowledge." ${ }^{3}$ Instead I subscribe to the notion of effort that Bacon and Midgelow unpack in relation to such assumptions, "effort to note and listen to the habits, sensations and articulations of the body. Effort for the words that might arise from such embodied attentiveness to come to the fore. Yes, effort, and practice, and time (for both the writer and the reader)."4 Here I take up the "effort" of working with the subjective as a position of valuing the instability and immeasurability of a poetic body. I also acknowledge my positioning and privilege as a white Australian woman and concede the limitations of this perspective in the world, as well as the patriarchal silencing that comes with it. My proposal is that the attention to energetic states in 
movement is performed inside the words on the page, and can be shared in a direct exchange between the reader and the dancer. This exchange needs to happen in a way that reader can still see and sense the dancer-see in a way that makes more room to experience the work, because while interacting with the words, the performance is in your hands, in your time - a body without borders. The agency is given to the reader "to move with a writer's own beat, needs a little bit of time."5

Through accessing and attending to a State of Dancingness, the project of writing as dancing aims to uncover the embodied texts of the dancer to make visible the energetic, choreographic and imaginative state of performance in words. In performance, the embodied knowledge of the dancer is translated kinesthetically to the audience. However, I have become increasingly interested in the hidden texts of the body not made explicit in this exchange. Maurice Merleau-Ponty argues that "the visible is pregnant with the invisible, that to comprehend fully the visible relations (house) one must go unto the relation of the visible with the invisible." $"$ The State of Dancingness prefaces the relationship of the dance with the dancer, to excavate emergent content toward an expanded readership for dance via the publication of embodied texts and creative non-fictions.

Writing as dancing manifests in three distinct ways; writing as a soloist, writing for the ensemble and writing responsively in collaboration. Resulting iterations thus far have variously emerged in the form of solo performance; she writes like she dances, ${ }^{7}$ novella; The Dancer in Your Hands,${ }^{8}$ play; Joni,${ }^{9}$ exhibition; Human, ${ }^{10}$ and long form poem-script she/herd. ${ }^{11}$ The words and form are forged from the body in a State of Dancingness with the dancer as author in the process of writing as dancing.

What is it our bodies know before we do, before we can name what it is we know? And how can we expand our boundaries of attention to match the speed of emergence? As Cixous clarifies "The emotion is born at the angle of one state with another state. At the passing, so brusque. Accident. Instant of alteration that takes us by surprise. And the body which expresses itself before the word." 12 The angle of dancing with writing, of writing as dancing, is an alteration that marks an opening for the dancer to speak, to be heard differently, to write herself out of hiding. Roland Barthes states, "What I hide with my language, my body utters."13 Following this guidance, writing as dancing can reveal what the body utters. Choreographer and performer Jennifer Monson called me "the evader" once, ${ }^{14}$ and I was drawn to the resistance I sensed in staying beyond each triggered and fast changing response in my improvised solo practice. The dancer as author in the State of Dancingness can continue between 
channels, in the form of words. The agency of the dancer as author enables access to a multiplicity of embodied experience presented as a series of singular publications, or solo work.

The State of Dancingness, as I apply it, is a harnessing of attention that acts as a force field or enlivened space to both rest in, and act from: a driven and directed application of attention in the body. This aligns with Cixous' "State of Drawingness" in her 1993 essay "Without End, No, The State of Drawingness, No, Rather: The Executioner's Taking Off," which is marked by a desire to get at the "quick of life." Primarily, the State of Dancingness is to do with tone and with accessing a live body that is available and open to perpetual response, compositional strategy and undoing. It is marked by an internal and dancerly drive that shifts from association to association and is acutely aware of changing momentum and emergent flights of curiosity. It supports the ability to notice decision-making in the moment of deciding and equally demands the ability to undo noticing in order to dance with the undecided, to reside in, and attune to not-knowing.

Dancers, I believe, are at the forefront of the concept and practice of embodiment that is now widely included in academic rhetoric, and, as Maggi Phillips said, "people who are immersed in movement, like dancers, might hold the keys to unlock some of the more profound puzzles of embodiment's role in thought." 15 The State of Dancingness draws on the response project in foregrounding the dancer as authority of embodied knowledge. ${ }^{16}$ The response project, developed as a series of improvisation scores for ensemble and solo practice during my Master of Arts (Creative Arts) in 2000-2001, is driven by quick shifting associational response systems and states of heightened attention to access physical imagination and lived experience. While writing as dancing has the response project as inbuilt methodology, it is also a shift away from it; I am more interested now in the time and stretch each portal of curiosity opens, in mining the life of a movement.

Begin where you are, teaches Deborah Hay, ${ }^{17}$ and that of course is crisis in the making. Said my Southern Italian ex-mother in law, "I do not need to find myself, I know where I am, I'm right here." She was, is, right. And yet with that seemingly limited locating of self comes exactly the beginning, or rather, the middling point. The State of Dancingness begins in the middle. In the middle of presence, "one must jump into the middle of the sheet of paper, fell the quill, as soon as the race begins, or else it's a battle." 18 What is the length of the life of a movement, what length is continuum? How long is love? How long does choice last? What is the length of leaving? Choose 
with an out clause, with windows, with a view, make the middle choose. Cixous writes "in truth the first line is the survivor of the mêlée: everything starts in the middle. ${ }^{19}$ The middle knows:

i. Begin Middle a fight about form, fuck the frame and fire

ii. Begin in the middle of development so it dies, your practice begins to kill things

iii. Begin End before the end

iv. Begin Middle Enter before begin

v. Begin as a nod to what you wrote before and when now comes after

vi. Begin Middle lifting the text of your legs and peel them back like sunburn

vii. Begin in middle hammering of the stage until you've built and given it away

viii. Begin after the hope that you might

ix. Begin because because

x. Begin Middle you fuck

xi. Begin Middle raining and catch it

xii. Begin by crossing out the middle

xiii. Begin writing over the top of each begun

xiv. Begin Middle differently

xv. Begin repeatingly begin begin begin

xvi. Middle tripping up tempo and pace

xvii. Begin Arrive in speed and stealth

xviii. Begin Middle arrive in disguise

xix. Begin backwards stay

xx. Begin 21 gun salute and lit attention

xxi. Begin orderly and fashionable

xxii. Begin b e t w e e $\mathrm{n}$ e very 1 e $t \mathrm{t}$ e $\mathrm{r}$ like the wanker that you are

xxiii. Begin thwack sound out

xxiv. Begin rotten

xxv. Begin in secret

xxvi. Begin again

xxvii. Begin Arrive Middle in the beginning thick

The perpetual unfixity in solo improvised dance performance ideally allows the work to be given away, to be owned by the viewer as a collection of kinesthetic responses, theatrical images and energetic states. What of a dancer who enters the word space with the same risk, trust in form, and presence as she enters the performance space? Many dancers write articulately of the experience of dancing, of inside dancing: Crisp, ${ }^{20}$ Longley, ${ }^{21}$ Gardner, ${ }^{22}$ Bacon, ${ }^{23}$ Foster,${ }^{24}$ and Parkinson, ${ }^{25}$ among others. In activating the State of Dancingness, I am both looking toward the act of writing as the centralization of embodiment, and investigating the capability of the professional 
dancing body to reorient the relationship between dancing and the act of writing. Between the movement and the energetic state of writing. Between the potential of a body experienced with expanded movement range and compositional attention, and the writing down of emergent content. The defense that the aliveness of performance reveals all is perhaps a withholding that enables silence, that enables hiding, that maintains a distance from declaration and difference. Paradoxically, dance can protect a dancer's right to remain hidden. I argue that new bodies of evidence are revealed in the creative non-fictions that result via the State of Dancingness.

As an artist who works between dance and writing, increasingly interested in publishing as performance, I work in a liminal space and concur with the assertion that still "the body and improvisation remains hidden." 26 In unpacking this State of Dancingness, I posit engagement with improvised dance practice as dynamically charged and a visible way of thinking that leads toward potential unhiding through writing. This practice of improvisation demands a keen excavating of energetic states and experience, and is an active choice to pay attention what is hidden or layered in the body toward a conscious unhiding rather than serendipitous revelation. The State of Dancingness requires an understanding of a set of compositional and performance principles practiced in solo dance improvisation, and the ability to move through them, to inhabit the borders, to stay in a practice of both writing and dancing: to be in two places at once, or in many places at once. It demands an active straddling and dismantling of borders; "sliding between the codifications of knowledge construction." ${ }^{27}$ This liminal place is where improvisational practice lives and, as such, can potentially both illuminate and activate gaps in knowledge construction.

Dance is rich with "presence," but the ambiguity of the dancer in attending to unhiding in live performance is immense. How then to write with presence inside the unhiding to reveal the dancer differently, how to write presence so it enables the reader to experience their own presence? As Caroline Bergval asks, "How does one create textual works where the authorial hold over the text is somehow distanced, perhaps neutralized, yet where the structural impact of experience, of living, of loving, of knowing, of reading, are in fact recognized." ${ }^{28}$ I propose that the dancer maintains agency, the writer maintains agency, the dancer responds, the writer responds, the work between them garners its own life, perhaps a more acute invitation to seeing than either one or the other. The dancer and the writer are the same person with the complicity of selves in an actively embodied duet or a solo for two. ${ }^{29}$ The expectation of performance. An energetic exchange. To resist or at least incorporate the absolute deluge of emergent 
content in bite sizes, and, also, dive into a longer staying. To see what the state is saying. To get underneath. To hide, to seek. To say it. While I found the spatial and compositional elements in the practice of writing as dancing relatively easy to apply in rendering emergent content on the page, I was surprised by was the nature of the content itself. What arose with fierce clarity in research was an uncovering of the "hiding" I had suspected was present behind the relative privacy of dancing.

The trace of the quick of life hidden beneath the rounded appearances of life, life which remains hidden because we wouldn't bear seeing it as it is. ${ }^{30}$

\section{Reorientation}

In harnessing the State of Dancingness in writing as dancing there is a queering of formal borders that provokes a reorientation of the dancing body on the page, a turning of sorts that is the central premise of my recently completed novella The Dancer in Your Hands. "Dance, with its poetic porosity and generative failure to convey direct meaning, engages productively and provocatively with queer's slippery, shapeshifting sensibility" 31 argues Clare Croft. Writing as dancing, I propose, continues this productive and provocative slippage in words. In alignment with Sara Ahmed's unpacking of relationship to object throughout her Queer Phenomenology, ${ }^{32}$ my laptop leans in without cover or skin, present and insistent, bossily contrary in asking me to "force quit." Small shut downs. I do not like to be without it. Constant studio and catchment of my dancing, carried parallel against ribs. I lean in, spine tilted toward pressing; little fingers my keels, anchors to the right and left. The physicality of punctuation. Puncture. Punctum. Press. Press. Press. Presence. Dance Dancer Dance. Turn Turn Turn.

The State of Dancingness enables the catching of a thought or energetic wave as a physical landing, a weighted concept, ready to be held, folded, creased, torn. This wave is visible in the dancing body, in the tracks of tug, sustained stretch, expansion, reduction or overlap. In writing as dancing, I type a rendering of my heartbeat the same way, composing on the page distance and time, height and variation, repetition and difference. An accumulation of sensation that turns beats into words. Tiny mountains of beating. Less one rhythm than many. Polyphonies. Multiple. Change of pace. The charge of pace.

Dancingness activates receptors. A practiced sense of listening, up to 3000 touch receptors in every fingertip. I bite my nails, the deliberate register of presence. 
Receptors in response to pressure, temperature, and in response to the narrative they arrest at the edges. I am acutely listening to less noise, to all of the noise at once, to pay attention to my body in the filling and emptying of the sound of typing. The sound of dancing. To trick myself into writing at the same time as thinking. To slow my process, speed, decision making in a way that matches the capability of pressing fingers. The movement of both hands. As conduit and actualizing event. The event of typing. The speed and sound and pace of writing as dancing. The urgency, consistency, silence in real sound, no scratching. Biting. Press. Fingertips rest on the central line of letters. Resting place, all in a row. Chorus lines. The democracy of keyboard. The frontal and central aspect of the screen. The order of the keys and the lines that remain, enabling thoughts to range without visible shift, then demanding decision inside the word making, rather than mark making, each letter pressed. Words have no democracy. They are quick to betray. The form of the screen holds the space like a studio. Edge of frame, words in the wings. Entering. Make an entrance. Word, make an entrance. Hands, enter. Letters, each one of you, step forward. Scroll. I barely look up, though I am not so proficient that when I am tired I write mostly with my eyes, looking actively for each letter b e f o r e it is pressed. Like Cixous, I want the "beforehand of a book" 33 when you can sense an entire work, and in that sensing of arrival, the imminence and anticipation of ending. So, I let go of the pressure in my teeth and catch up with myself. Fingers as conductors, mapping worlds in front of me, the responsibility of both hands. Thinking in time with the body, slows, accelerates, arrives differently, arrives in the middle, arrives embodied. Deciding to press.

As an improviser, I work with the life of any given movement. The life of each thread, the length of each question and each convolution of curiosity. But in these different lengths and lives of movements, I am aware of a continuing tone; from association to association, from response to response, as a state without end. By employing a radical impermanence as "an active commitment to the moment you understand is simultaneously disappearing," ${ }^{34} \mathrm{I}$ aim to rupture this continuum of associational shifting to encourage a perpetual presence. Staying with leaving enables a deeper excavation of where you are without the need to escape immediately to the next association or respond to the next distraction. The attention, density, and critical vulnerability in The State of Dancingness conspire toward rupturing this sense of "without end" to catch and further mine the middle of feeling, the middle of being. It is driven by an embodied experiment of writing as dancing as: 

a) Invocation
b) Excavation
c) Disclosure
d) Turning
e) Presence
f) Unhiding
g) Relief
h) Decision
i) Rapture
j) Exactness
k) Slippage
1) Attention
m) Pace
n) Tone
o) Attending
p) Middling
q) Response
r) Turning
s) Undoing
t) Standing
u) Forgetting
v) Biting
w) Pressing
x) Waking
y) Failing
z) Arriving Staying with leaving

The seemingly stochastic defining of the State of Dancingness is as important as it is to the dancer in attending and responding to an ever changing present; the constant lies in both its unfixity and virtuosic attention. ${ }^{35}$ Improvisation foregrounds the decision making and activated response of the dancer. I access this State of Dancingness when I am improvising in dance. I access this same State of Dancingness in writing. The State of Dancingness enables a narrative project of writing inside acute understanding of composition and physical attention. The written work is in and of the dance and the dancer, imbued with choreographic structure, performance, presence, physicality, weight.

Australian Dancer and Professor Rebecca Hilton's proclamation of DANCERNESS is important ground in the provocation of what the State of Dancingness might bring to writing:

DANCERNESS is the very particular way/place/state from which a dancer experiences a dance, the choreography, the world. I've been thinking a lot about how unremarked upon, even unrecognized, dancer knowledge - 
DANCERNESS, is. Dancers think, feel and act upon the world in a particular way. ${ }^{36}$

My work in developing writing as dancing aspires to make visible embodied knowledge through mining the dancers' ability to physically inhabit creative process. As Rebecca Hilton states, "dancers have the ability to comprehend information at the very point at which our experience of ourselves ends and our experience of the rest of the world begins. And vice versa. I think that dancers give us access to this specialized noticing. ${ }^{37}$ When Hilton asks "Maybe we dancers actually experience the world in an ontologically different way?"38 I foreground that it is with a dancers' experience that I have undertaken this research and that DANCERNESS is pivotal in my written texts. Narratives emerged imbued with my performance idiolect of repetition, fragmentation, and associational shifts as in this excerpt from The dancer in your hands:

In the winter I drowned my fingers in the winter in the winter she cradled them each tiny bitten pocket of attention in the winter her jaw gave opening in the winter to breasts splayed in the winter softened in the winter held in the winter wet in the winter no bitter in the winter no incline in the winter she is tired in the winter in the time between summer in the time between winters in the time between light and light in the winter sounds far in the winter calls repeat in the winter sound her sleep her in the winter raise and fire her in the winter save her in the winter situate her dire in the winter make her laugh in the winter what in the winter are you naming of this recording in the winter what beginning in the winter what initial what future what allowance in the winter what leaves and bough in the winter what pen and frame in the winter what mind and love what break and cast what flight what scene what day what date what time what fate in the winter they all left in the winter bar one in the winter who stayed in winter hair pulled back and regal in the winter authority in winter tender in the winter does not leave in the winter not even in leaving in winter in love in the winter leaving in the winter turn in the winter turning into winter turn turn

divided

She is me. She is dancing. She is not her lover. She is other. She is not him. He is me. He is the last stop. Stopped. She is the go. She is her own delay. She is her other. There is a conversation. You are talking, you are she. You are her. Or you are he. She is we. In the turn of your hands and my overlapping lines. The turn of your hands in my overlapping lines. The turn of your hands in my overlapping lines. In the turn of your hands and

my overlapping lines The turn of your hands in my gverlapping lines The turn of xour hands andmy overlapping lines the turn of your hands in mey over lapping lines The turn. of your hands in piy overlapping lines The turn of your hands on my hands in my overlapping lines the turn of your hands in my oyerlapping lines 1 he turn ofyour hands inmyoverlapping lines Phe turn of wour hands in my overlapping lines the turn of ypur hands in my overlapping lines The turn of ypur hands til my handapping ines la turn of your hands in my qverlapping lnes one.turn. of ypur

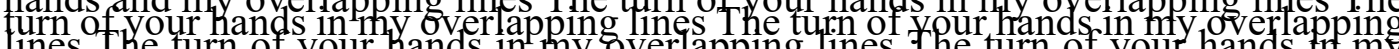
overlapping lines The turn of your hands in my overlapping lines The turn of your 


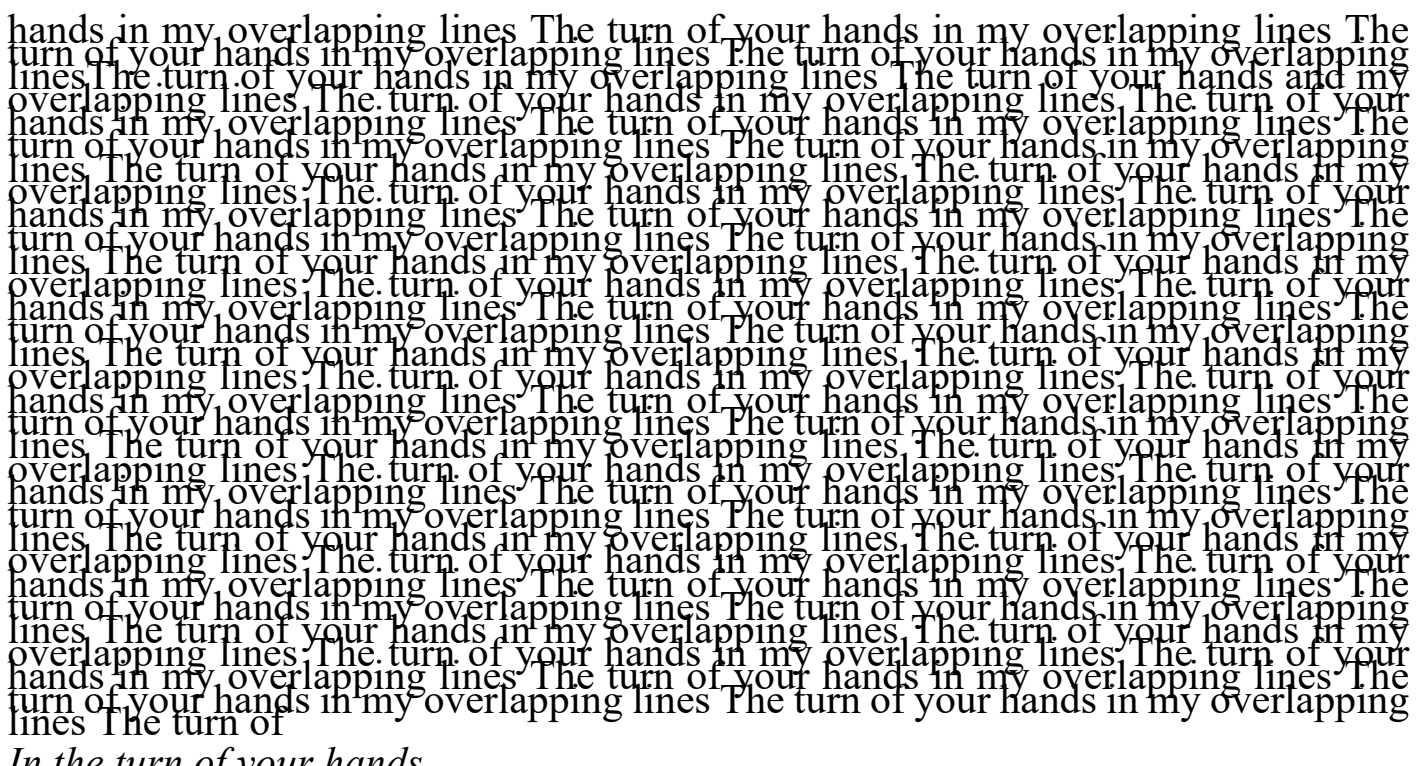

In the turn of your hands.

divided

adrenaline sweeps tops of forearms and fingers far bitten collect like vestibules like estuaries like fucking suburban cul-de-sacs on the for-sale sign keeping our children safe. you are holding the dancer in your hands. hold her. five extra beats. the sound of beating. soundtrack of speed faster than she can count. the tracking of beating. one two three four five. the sound of acceleration. she stands behind each beat in anticipation. catches the tail wind the echo the tug the taking. it is dark. it is too light. the hours press in. there is no room. off with her head. she pushes thoughts into her legs like rescue, like lactic acid. like the grief of stillness. this is the part where they all fall out. the soundtrack of arrhythmia. this is a manifesto that can go and fuck itself. in long form. long form fucking. everything is too long, except marina abramovich who just sits there. everything is too short. off with her head. this is unequal. this is notice. this is the offer. turn over. turn, turn, turn. everyone corners into concrete. the tree roots were illusion, the pliable branches, changing leaves. c o n c r e t e. tricked by trees.

divided

divided

Charge her with treason to familial code/Charge her with deception/Charge her with losing sight/ Charge her with losing site/ Charge her with ambiguity/Charge her with crisis/ Charge her with change /Charge her double/Charge her /Charge / her / with/ Charge her/ Charge / Charge / charge / charge / charge / charge / charge / charge / charge / charge / charge / charge / charge / charge / charge / / /

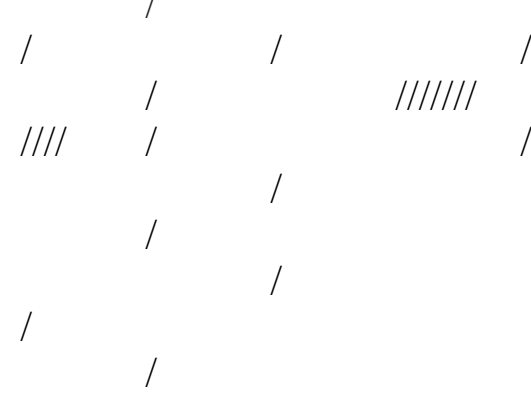


Off with her head /

I held her head in my hands in my hands in my hands

One must think faster than oneself ${ }^{\beta 9}$

Certainly by fore fronting the presence, scores and energetic states inherent in dance improvisation via the act of writing, words arrive faster than I can catch them, but catching them is the practice and the vehicle I know, and so I persist. The dramaturgy of each word caught is through the lens of writer, performer, choreographer and editor but it is as dancer that I engage with an uninterrupted flow, to uncensor and reveal unexpected trajectories and narrative.

You will recognize the true drawing, the live one: it's still running. Look at the legs. ${ }^{40}$

The rethinking of sound and movement carried out by Cage (1961), ${ }^{41}$ Rainer (1963), ${ }^{42}$ and others, revolutionized music and dance, opened a space for dance as "text." Cixous' interrogation of the potential of a "State of Drawingness" prompted my thinking that embodied knowledges can bring the work of the author to the fore, in front of the author. As Della Pollock describes, the ability to create is more than the sum of the author themselves:

Entanglement, ravishment, love, writing: what I want to call performative writing does not project a self, even a radically destabilized one, as much as a relation of being and knowing that cuts back and forth across multiple 'divisions' among selves, contexts, affiliations. ${ }^{43}$

The embodiment project in dance today remains, as performance philosopher Bojana Cevjic describes, an "organic regime" 44 aligned with somatic, physical and "ineffable" practices that primarily locate in and of the dancing/performing/present body. What if the physicality and practice of the dancer arrived in the form of writing, in the form of words, not as documentary or encounter of the experience of dancing, but as material emergent from the dancer produced as dance, in words?

We might have to shift attention from the work of performance to an expanded notion of choreography and performance, which may include its own selftheorization as a poetics and a practice. Such a thinking wouldn't only involve activities that bring performances into existence, or sustain them, but would also 
have to consider which forms of labor and life choreography as a practice depends on and gives rise to, while also considering - outside the disciplines of dance and performance - other media, situations, and modes of attention to the moving body. ${ }^{45}$

Cevjic's discussion of improvisation is noteworthy in its dissenting voice of the form as being intrinsically linked to the body and therefore empirical knowledge "which keep dance hermetic, away from anybody who doesn't have the empirical privilege of access, that is to say, the know-how and experience of training, dancing, and watching dance." ${ }^{46}$ While her book Choreographing Problems is vital reading in advocating for expansive parameters for dance as contributive to performance philosophy, and I concur with most claims, again it posits a sort of suspicion of the improvising dancer as author as potentially not able to move wider than itself due to the personal "organic" nature of the work. And here I turn to the ongoing feminist projects of visibility and multiplicity to engage with the premise that feeling states can be excavated and attended with microscopic and rigorous composition inside gaps of known thinking that might still be dormant, and in waiting to be written.

The demands of an improviser to be fully present and "live" in the moment of performance is charged with the ability to continuously be in a state of leaving the moment/movement/passion that passes. Staying with leaving enables risk taking and a quickly shifting set of responsibilities to invite the unexpected, trusting but not beholden to where you have been. A polyamorous attention. This same liveness is what is cultivated in writing as dancing. The work stands both with the presence and with the absence of the author as she leaves. The liveness remains in the pages, of the dancer, the agency both in the text and ultimately, in the hands of the reader. There is paradox in writing as dancing in both wanting to forefront the dancer while simultaneously allowing her disappearance. The physical absence of the dancing body imbues the text with an urgent embodiment toward revealing the work of the dancing in a different language. The process that precedes the pressing is the dancer turning. I "die" on Barthes' terms, yet remain elusively present in the energetics of the text, and in the quality of your turning each page, forward and backwards. The project of recognizing the dancer as author of the work neither imposes a "stop clause" or "final signification" as Barthes suggests. ${ }^{47}$ Rather than "close the writing," the work of the writing, with the visibility and presence of dancer as author, remains open precisely because the improvising dancer is expert at unfixity, the dancer has moved on to the next, the dancer leaves. The dance remains as sentient labyrinth of openings, turns, and returns. The conversation then, one of intimacy and presence, with the dancer present. 
We live more quickly than ourselves, the pen doesn't follow. To paint the present which is passing us by, we stop the present. One cannot after all write a book with only one stroke, of only one page, and yet we should. But we are born for lateness. Time, the body, are our slow vehicles. ${ }^{48}$

Initially I created scores like "write yourself into dancing" and "dance yourself into writing" and with practice, I stayed longer and longer with words. I practiced these scores until I could sit to write with my body embodied with a State of Dancingness. The ability to turn on the State of Dancingness began to continue beyond the dancing. Writing as dancing, toward generating creative texts imbued with a State of Dancingness is a methodology I have trialled and seen it develop in my undergraduate students, and in artists I have mentored - including Australian choreographer Rhiannon Newton:

it's like vocabularies opening up as well as a clarity of seeing and begin able to differentiate what's happening, and at same time vocab increasing, the same way you develop new movement pathways opening you develop sort of neuro connections from noticing a different kind of textual quality and having more access to that language that can differentiate that from something else (in) a greater sort of flow between the worlds of talking about dancing and talking about ideas, being able to articulate them in writing, some sort of flexibility between what would've been my tendency towards formulaic or structural sorts of approaches of things to where the poetry was allowed to also enter into the language. ${ }^{49}$

The relationship of dancer as writer in the emergence of embodied texts is grounded in the dancer writing as dancing. In presenting the written words as danced solo in the form of a novella, The Dancer in Your Hands, I am inviting criticism of the work in the same way as I would of a performed solo. Peter Eleey asks “are Trisha Brown's drawings more art than dance, or more dance than art? Moreover, is it possible (or even helpful) to try to discern the difference?" Eleey here is forefronting the value of the presence of the dancer in the work "Having not yet entered the stage, or already left, Brown is neither here nor there. This ghostly, muddled location of her body and its movements vis-à-vis her drawings — proceeding from or preceding them — is crucial to their function as artworks." ${ }^{\circ 5}$ The agency of dancer as author, both present and absent in the text, marks potential new ways of engaging with the dance as a reader.

I see with my ears ${ }^{51}$

The dancer asserting her performance as publication is a potential betrayal to a 
traditional field of current mainstream contemporary dance, which aligns with dancing bodies on stage. In aligning with Cixous' "to-be-in-the-process of writing and drawing," 52 I am raising the potential of the State of Dancingness to work in the nexus between writing and visual poetry as a performance you can hold in your hands: a printed performance that sees the reader and dancer reside together in the embodiment of the text, a liminal space that houses both rather than one at the cost of the death of the other and potentially opens to the possibility of more-than-human practices. ${ }^{53}$ Cixous' process of drawing to "unearth" the writing gives voice to writing as dancing in generating an embodied attention with potential to unhide or "dance" forth hidden truths. I wanted to see what it was I was saying. I wanted to see what I meant. What the content was. To turn around and stand in front of the ambiguity of giving it all away, and still the moment. I wanted to listen. To work in the same way as dancing, to listen to emergent content, and to see what happened to that State of Dancingness in words. "I seek the truth, I encounter error. How do I recognize error? It is obvious, like truth. Who tells me? My body." 54 As an improviser, I am ever moving to the next, here I am interested in what happens upon staying. To follow or engage in a single window, train of thought or portal, opens of course into its own minefield of associations, distractions, demands and delights. And the splintering then is infinite. What do you do when you cannot stay? You stay with leaving.

The ambiguity enabled in the dancing body is rich and unaccountable, even to itself. As Cixous says, "it's not a question of drawing the contours, but of what escapes the contour, the secret movement, the breaking, the torment, the unexpected." 55 I am investing in writing as dancing and the State of Dancingness as a way to attend to, and uncover, the between of dancing and writing, in order to try and catch what it is that the body knows before I do. Imagination and emotion, muscle and tone-the response project in full flight. Inside sensing, doing being. Staying with leaving. Where is the delay in the body on screen, in the comma? In the silence loudly sounded between pressings? When the fingers rest, when the keys pause? The cursor, insistence and constant of pulse, blinking, pushing through stage front. A tiny vertical line|, holding the space. Quietly. The State of Dancingness enables the act of writing with the simultaneous positions of dancer and writer to be less divided $<\|>$ The dancer stays. / / /

In your hands her hiding. Hands as a hiding place. Pull her spine apart. Gently. Prise. To make more space. To breathe in read. Dance is her alibi. This telling her seek. I would be happy to hit the wall should that be your finding. To be thrown. Dance 
dancer dance. Stay. Stay longer than you can. Stay. End it here. Part the middle. Rest. Stay in the part. Stand. Step back. Step up. Stand. Stay. Wait. Open. Stay. Wait. Gaze.
Hold.
Step in. Press.
Breathe.
Stay.

Lean. Retreat. Whip.

Press. ........... . Dissolve.

Fall.

Stay.

Press.

Be pressed.

Wait.

Expect.

Counter.

Push.

Press. Pull.

Grasp.

Soften .

Gasp.

Open.

Fall. Press. Stay. Stay. Stay.

Stay $/ \mathrm{v} \vee \wedge / \mathrm{v} \backslash \mathrm{v} / \wedge \wedge \mathrm{v} / . . \ldots \ldots \ldots \ldots$

${ }^{1}$ Helene Cixous, "Without End, No, The State of Drawingness, No, Rather: The Executioner's Taking Off" (1993) in Stigmata, trans. Catherine A. F. MacGillivray (New York: Psychology Press (2005), 16-29.

${ }^{2}$ How I "write like I dance" is discussed at length in Jo Pollitt, "She Writes Like She Dances: Response and Radical Impermanence in Writing as Dancing," Choreographic Practices 8, no 2 (2017): 199-218. doi: 10.1386/chor.8.2.199_1

${ }^{3}$ Jane Bacon and Vida Midgelow, "Articulating Choreographic Practices, Locating the Field: An Introduction," Choreographic Practices 1, no 1, (2011): 3-19.

${ }^{4}$ Ibid., 9

${ }^{5}$ Jeanette Winterson, Art Objects, Essays on Ecstasy and Effontery, (London: Vintage Books, 1995), 89.

${ }^{6}$ Maurice Merleau Ponty, The Visible and the Invisible, ed. Claude Lefort, trans. Alphonso Lingis (Evansville: Northwestern University Press, 1968), 216.

${ }^{7}$ Jo Pollitt, "She Writes Like She Dances" in Turn Three: On Score at Performing, Writing, Bats Theatre, March 14, 2017, Wellington, New Zealand

${ }^{8}$ The dancer in your hands, a novella $<>$ is the creative component of my $\mathrm{PhD}$

9 Script developed for Chrissie Parrott's work "TransAction," Perth Institute of Contemporary Art, 2017

${ }^{10}$ Lilly Blue and Jo Pollitt, "Human" BIG Kids Magazine \#10 and exhibition of the same name at Manly Museum and Art Gallery, 2017

${ }^{11}$ Jo Pollitt, "She/herd," script for Chrissie Parrott's InLore Act II (WA Dance Makers Season, CO3, State Theatre Centre, Perth, Australia, September 2018)

${ }^{12}$ Cixous, 23.

${ }^{13}$ Roland Barthes, A Lover's Discourse: Fragments, (New York: Hill and Wang, 1978), 44.

${ }^{14}$ Monson worked with me on an improvised solo titled prince performed at PICA, Perth, Australia, 2001.

15 Maggi Phillips "Skipped States of Lightness: A Failure of Knowledge" Axon: 
Creative Explorations 2, no 1, 2012. https://www.axonjournal.com.au/issue3/skipped-stakes-lightness

${ }^{16}$ Joanna Pollitt, Accumulated Response in Live Improvised Dance Performance, (MA thesis, Edith Cowan University, Australia, 2001).

17 Deborah Hay, My Body the Buddhist, (Middletown, Wesleyan University Press, 2000).

${ }^{18}$ Cixous, 25.

${ }^{19}$ Ibid.

20 Rosalind Crisp, "Re-membering the Body: Investigating a Process," Double Dialogues 2, Winter 2002. http://www.doubledialogues.com/article/remembering-the-body-investigating-a-process/.

${ }^{21}$ Alys Longley, the foreign language of motion (Winchester: Winchester University Press, 2014).

22 Sally Gardner. "Praticising Research, Researching Practice; Thinking through Contemporary Dance" Cultural Studies Review 18, no 1 (2012): 138-152.

${ }^{23}$ Jane Bacon and Vida Midgelow "Closer to the Body: Reflections on Skript and Extracts from Collected Writings," Choreographic Practices 5, no 1 (2014).

24 Susan Leigh Foster, Dances that Describe Themselves, The Improvised Choreography of Richard Bull. (Middletown: Wesleyan University Press, 2002).

${ }^{25}$ Chryssa Parkinson Self interview on Practice (2009). https://vimeo.com/26763244

26 Vida Midgelow, Keynote Performance. Improvisation Institute: International Institute for Critical Studies in Improvisation, 2018

${ }^{27}$ Ibid.

${ }^{28}$ Caroline Bergval, "The Conceptual Twist" in I'll Drown My Book-Conceptual writing by Woman, (Los Angeles: Les Figues Press and the Authors, 2012), 21.

${ }^{29}$ Solo for Two is a score developed for my Response Project in 2001, where two performers work side by side to perform one solo. Here I reapply the score to the duel practitioners - engaging both the dancer and writer-in a simultaneous practice of solo writing and publication as performance.

${ }^{30}$ Cixous, 21.

${ }^{31}$ Clare Croft, Queer Dance, (New York: Oxford University Press, 2017), 10.

32 Sara Ahmed, Queer Phenomenology: Orientations, Objects, Others, (Durham and London, Duke University Press, 2006).

${ }^{33}$ Cixous, 16.

${ }^{34}$ Pollitt, "She writes like she dances, Response and Radical impermanence in Writing as Dancing," 201.

35 Virtuosic attention, in this work, is an amplification of choreographic thinking through the noticing of energetic state and embodied imagination. It is a term I've also heard used individually by Australian choreographers Rosalind Crisp and Paea Leach.

${ }^{36}$ Rebecca Hilton, SPECIFIC IN-BETWEEN: The choreographic negotiated in six parts, (Australian Centre for Contemporary Art, 2014), 196. 
${ }^{37}$ Ibid., 198

${ }^{38}$ Ibid.

${ }^{39}$ Cixous, 26.

${ }^{40}$ Ibid., 17.

${ }^{41}$ John Cage, Silence, (Hanover: Wesleyan University Press, 1961).

42 Yvonne Rainer, Terrain, (New York, Judson Memorial Church, April 28, 1963).

${ }^{43}$ Della Pollock, "Performing Writing," in The Ends of Performance, eds. Peggy Phelan and Jill Lance (New York: NYU Press, 1998), 73-103, 86.

${ }^{44}$ Bojana Cevjic, Choreographing Problems: Expressive Concepts in Contemporary Dance and Performance (London: Palgrave Macmillam, 2015).

${ }^{45}$ Ibid., 229.

46 Ibid., 226.

${ }^{47}$ Roland Barthes, "The Death of the Author," (Aspen 5+6, 1967). http://www.ubu.com/aspen/aspen5and6/threeEssays.html\#barthes

${ }^{48}$ Cixous, 26.

${ }^{49}$ Rhiannon and I worked intensively on her Checkpoint Solo (2009) during which time my early writing experiments were trialed between my home in WA and hers in Israel. This quote is from an interview at Readymade studio, Sydney, 31 July, 2016.

${ }^{50}$ Peter Eleey, "If You Couldn't See Me: The Drawings of Trisha Brown," in So That the Audience Does Not Know Whether I Have Stopped Dancing, (Minneapolis: Walker Arts Centre, 2008), 19.

${ }^{51}$ Cixous, 17.

52 Ibid., 91.

${ }^{53}$ The scope of this paper does not permit discussion of the more-than-human (see Braidotti, The Tanner Lectures, March 1-2, 2017; Latour, The Anthropocene Lecture, May 4, 2018; and Blaise, Fabricated childhoods: uncanny encounters with the more-than-human, 2015, for a discussion of more-than-human worlds) I include reference to it as it invites thinking about materiality of the book as a dance or dancer, and that new knowledge might be keened in these more-than-human experiences of embodiment.

${ }^{54}$ Cixous, 18.

${ }^{55}$ Ibid., 19. 